\title{
Zasady opodatkowania osób samotnie wychowujących dzieci i ich ewolucja
}

Transformacja ustrojowa zapoczątkowana w końcu lat 80. XX w. stała się przyczyną szeregu zmian, m.in. w sferze społeczno-gospodarczej. Te z kolei były impulsem reformy systemu podatkowego. Nieodzowne było bowiem dostosowanie go do nowych warunków gospodarczych. Konieczne stało się m.in. opracowanie zmienionej koncepcji opodatkowania dochodów osób fizycznych.

Zasadniczym celem niniejszego opracowania jest wskazanie, czy i ewentualnie w jakim zakresie zreformowany podatek dochodowy uwzględnia sytuację rodzin niepełnych. Za zasadne uznano również wskazanie przyczyn leżących u podstaw przyjęcia rozwiązań prorodzinnych na gruncie obowiązujących regulacji prawnych, a także kierunków przeobrażeń charakteryzowanych instytucji.

W systemie opodatkowania dochodów osób fizycznych najistotniejsze miejsce zajmuje podatek dochodowy od osób fizycznych ${ }^{1}$. Jest to podatek osobisty, nawiązujący do zdolności podatkowej podatnika, a zatem w doktrynie prawa podatkowego przyjmuje się, że podatki tego typu pozwalają na realizację w najszerszym zakresie zasady sprawiedliwości podatkowej². Progresywne opodatkowanie w podatku dochodowym jest również uzasadnione społecznie jako instrument redystrybucji dochodów, w związku z czym odpowiada założeniom państwa socjalnego, stanowiąc równocześnie przeciwwagę regresji w podatkach pośrednich ${ }^{3}$.

Należy też zwrócić uwagę na podstawowe zasady leżące u podstaw konstrukcji aktualnie obowiązującego podatku dochodowego od osób fizycznych. Jedną z nich stanowi powszechność opodatkowania, którą należy utożsamiać

* Dr Katarzyna Święch - Katedra Prawa Samorządu Terytorialnego, Wydział Prawa i Administracji, Uniwersytet Szczeciński.

${ }^{1}$ Ustawa z dnia 26 lipca 1991 r. o podatku dochodowym od osób fizycznych (t.j. Dz. U. z 2010 r. Nr 51, poz. 307 ze zm.).

2 Por. J. Szpunar, Zdolność płatnicza ludności a podstawa opodatkowania, „Ruch Prawniczy, Ekonomiczny i Socjologiczny" 1963, nr 1, s. 146 i n.; I. Bolkowiak, Zdolność płatnicza a podstawa opodatkowania w podatku dochodowym od osób fizycznych, [w:] A. Pomorska, Kierunki reformy polskiego systemu podatkowego, Lublin 2003, s. 217.

${ }^{3}$ H. Litwińczuk, P. Karwat, Prawo podatkowe przedsiębiorców, t. I, Warszawa 2008, s. 77. 
z jednolitym opodatkowaniem dochodów osobistych osób fizycznych ${ }^{4}$, i może być rozpatrywana $\mathrm{w}$ ujęciu podmiotowym oraz przedmiotowym ${ }^{5}$. W pierwszym z tych ujęć powszechność oznacza opodatkowanie każdej osoby fizycznej uzyskującej dochód. W aspekcie przedmiotowym powszechność opodatkowania sprowadza się do uznania za przedmiot opodatkowania wszystkich źródeł przychodów i opodatkowania sumy uzyskanych przez osoby fizyczne dochodów, co wyklucza funkcjonowanie zwolnień przedmiotowych ${ }^{6}$.

Za jedną z podstawowych zasad opodatkowania dochodów osób fizycznych należy również uznać indywidualne opodatkowanie każdej osoby fizycznej. Wyjątki od niej wprowadzają przepisy odnoszące się do metody łącznego opodatkowania członków rodziny. Wśród nich można wymienić opodatkowanie osób samotnie wychowujących dzieci.

W pierwszej kolejności warto zatem wskazać na uzasadnienie wprowadzenia tej instytucji (jako wyjątku od zasad ogólnych) do konstrukcji podatku dochodowego od osób fizycznych. Za zasadniczy argument przemawiający za stosowaniem wskazanej instytucji można uznać przesunięcie ciężaru utrzymania dzieci w rodzinach niepełnych tylko na jedną osobę ${ }^{7}$ W związku z tym opodatkowanie osób samotnie wychowujących dzieci, jako wpływające na redukcję obciążenia podatkowego, powinno być traktowane jako rozwiązanie o charakterze prorodzinnym, będące instrumentem realizacji polityki prorodzinnej państwa.

Należy jednak podkreślić, że nie jest to instytucja oceniana jednoznacznie zarówno ze względu na odmienne podejście do wszelkich przywilejów podatkowych, jak i ze względu na obawy, że przyjęcie takiej formuły może skutkować stwarzaniem sztucznych przesłanek (fikcyjnych rozwodów) do jej stosowania przez osoby o wysokich dochodach ${ }^{8}$. Uzasadnione więc wydaje się odniesienie do kolejnych nowelizacji ustawy w omawianym zakresie. Przede wszystkim należy zauważyć, że charakteryzowana instytucja nie obowiązuje od chwili wejścia w życie ustawy o podatku dochodowym od osób fizycznych; do obrotu prawnego została wprowadzona w 1993 r. ${ }^{9}$, z mocą obowiązującą od 1 stycznia

${ }^{4}$ A. Piotrowski, Zasady ogólne podatku dochodowego od osób fizycznych, „Przegląd Podatkowy" 1993 , nr 12, s. 9.

5 W. Wójtowicz (red.), Prawo podatkowe - część ogólna i szczegółowa, Warszawa 2009, s. 259; I. Bolkowiak, Jak opodatkować wynagrodzenia za prace, „Finanse” 1983, nr 3, s. 28.

${ }^{6}$ Opodatkowanie dochodu globalnego wymaga jednocześnie precyzyjnego określenia katalogu źródeł przychodów; R. L. Deutch, S. J. Gates, M. M. Gibson, P. J. Hanley, G. L. Payne, W. S. Plummer, Australian Tax Handobook 1997, Sydney 1997, s. 33.

7 Por. Z. Ofiarski, Wybrane aspekty opodatkowania dochodów osób samotnie wychowujących dzieci, [w:] M. Andrzejewski, L. Kociucki, M. Łączkowska, A. Schulz (red.), Księga Jubileuszowa Profesora Tadeusza Smyczyńskiego, Toruń 2008, s. 560.

${ }^{8}$ A. H. Nowak, Opodatkowanie dochodów rodziny, „Monitor Podatkowy” 1995, nr 11, s. 326.

${ }_{9}^{9}$ Art. 6 ust. 4-7 dodane art. 1 pkt 2 ustawy z dnia 6 marca 1993 r. o zmianie niektórych ustaw regulujących zasady opodatkowania oraz niektórych innych ustaw, Dz. U. Nr 28, poz. 127. 
1993 r., czyli ten sposób opodatkowania mógł być stosowany już do rozliczenia dochodów osiągniętych w 1993 r. Warto zwrócić uwagę na fakt, że od chwili wejścia w życie omawiana instytucja podlegała zasadniczym zmianom, będącym wynikiem orzeczenia Trybunału Konstytucyjnego i następnie wstąpienia Polski do Unii Europejskiej. Uzasadnione zatem wydaje się przytoczenie przepisu $\mathrm{w}$ jego pierwotnym brzmieniu, zgodnie z którym podatek dochodowy od osób samotnie wychowujących dzieci przez cały rok podatkowy mógł być ustalony na wniosek wyrażony w rocznym zeznaniu podatkowym, w podwójnej wysokości podatku obliczonego od połowy dochodów osoby samotnie wychowującej dziecko. Za osobę samotnie wychowującą dzieci uznano rodzica albo opiekuna prawnego stanu wolnego: pannę, kawalera, osobę rozwiedzioną, wdowę oraz wdowca. Z tej formy opodatkowania nie mogli jednak skorzystać członkowie rodzin, w których dochód na jedną osobę przekraczał 2500000 zł miesięcznie (przed denominacją). Powyższe ograniczenie kwotowe zostało uznane za niezgodne z Konstytucją na mocy orzeczenia Trybunału Konstytucyjnego z dnia 11 kwietnia $1994 \mathrm{r} \cdot{ }^{10}$ Podstawą takiego rozstrzygnięcia było odwołanie się przez TK do konstytucyjnej zasady równości. Przy czym wskazano, że cechą istotną różnicującą podatników jest m.in. fakt samotnego wychowywania dzieci. Zróżnicowanie pozycji osób samotnie wychowujących dzieci w stosunku do pozostałych podatników jest więc w pełni usprawiedliwione. $Z$ reguły bowiem sytuacja materialna takich osób jest gorsza i tym uzasadnione jest preferencyjne opodatkowanie. W związku z tym zróżnicowanie obywateli ze względu na kryterium samotnego wychowywania dzieci jest zgodne z Konstytucją. Za niezgodne z nią uznać natomiast należy dalsze rozróżnienie $\mathrm{w}$ ramach klasy rodzin niepełnych, uzależnione od wysokości dochodu na członka rodziny. Podatnik ma wyjątkowo mały wpływ na treść stosunku podatkowoprawnego, dlatego ustawodawca powinien $\mathrm{z}$ dużą wrażliwością dbać o to, aby wobec wszystkich podatników stosować jednakowe reguły ${ }^{11}$. Cytowany fragment uzasadnienia orzeczenia TK uznać można równocześnie za uzasadnienie obowiązywania wskazanej techniki opodatkowania rodzin niepełnych.

Na gruncie aktualnie obowiązującej ustawy o podatku dochodowym od osób fizycznych, od osób objętych nieograniczonym obowiązkiem podatkowym, samotnie wychowujących $\mathrm{w}$ roku podatkowym dzieci:

1) małoletnie;

${ }^{10}$ Orzeczenie Trybunału Konstytucyjnego z dnia 11 kwietnia 1994 r., K 10/93, OTK 1994, część I, poz. 7. Przepis, na podstawie którego został derogowany art. 6 ust. 6 ustawy o podatku dochodowym od osób fizycznych utrzymał jego moc obowiązującą w okresie od 1 stycznia $1993 \mathrm{r}$. do 31 grudnia 1993 r., a zatem obowiązywał dla ustalenia wysokości podatku za 1993 r., tym samym nie ziściła się przesłanka umorzenia postępowania przed Trybunałem Konstytucyjnym.

${ }^{11}$ Uzasadnienie orzeczenia Trybunału Konstytucyjnego z dnia 11 kwietnia 1994 r., K 10/93, OTK 1994, część I, poz. 7. 
2) bez względu na ich wiek, które zgodnie $z$ odrębnymi przepisami ${ }^{12}$ otrzymywały zasiłek (dodatek) pielęgnacyjny lub rentę socjalną;

3) do ukończenia 25. roku życia, uczące się w szkołach, o których mowa w przepisach o systemie oświaty ${ }^{13}$, przepisach o szkolnictwie wyższym ${ }^{14}$ lub w przepisach regulujących system oświatowy lub szkolnictwo wyższe obowiązujących w innym niż Rzeczpospolita Polska państwie, jeżeli w roku podatkowym nie uzyskały dochodów podlegających opodatkowaniu na zasadach określonych we wskazanych przepisach ustawy (art. 27 lub art. 30b) w łącznej wysokości przekraczającej kwotę stanowiącą iloraz kwoty zmniejszającej podatek oraz stawki podatku, określonych w pierwszym przedziale skali podatkowej, z wyjątkiem renty rodzinnej

- podatek może być określony, z zastrzeżeniem wynikającym z ustawy, na wniosek wyrażony w rocznym zeznaniu podatkowym, w podwójnej wysokości podatku obliczonego od połowy dochodów osoby samotnie wychowującej dzieci, z uwzględnieniem zasad dotyczących opodatkowania dochodów małoletnich, z tym że do sumy tych dochodów nie wlicza się dochodów (przychodów) opodatkowanych w sposób zryczałtowany na zasadach określonych w tej ustawie.

Komentując powołany przepis ustawy, należy w pierwszej kolejności zauważyć, że wejście Polski do Unii Europejskiej stało się bezpośrednią przyczyną kolejnej nowelizacji zasad opodatkowania osób samotnie wychowujących dzieci. Przyjęto bowiem, że ta metoda może być również stosowana przez osoby, na których ciąży ograniczony obowiązek podatkowy, samotnie wychowujące w roku podatkowym dzieci, jeżeli łącznie spełniają następujące warunki:

1) mają miejsce zamieszkania dla celów podatkowych w innym niż Rzeczpospolita Polska państwie członkowskim Unii Europejskiej lub w innym państwie należącym do Europejskiego Obszaru Gospodarczego albo w Konfederacji Szwajcarskiej;

2) osiągnęły podlegające opodatkowaniu na terytorium Rzeczypospolitej Polskiej przychody w wysokości stanowiącej co najmniej 75\% całkowitego przychodu osiągniętego w danym roku podatkowym;

3) udokumentowały certyfikatem rezydencji miejsce zamieszkania dla celów podatkowych

- z zastrzeżeniem, że i w tym przypadku obowiązują ograniczenia wynikające z pozostałych ustępów wskazanego artykułu.

Na żądanie organów podatkowych lub organów kontroli skarbowej podatnicy samotnie wychowujący dzieci są obowiązani udokumentować wysokość całkowitych przychodów osiągniętych w danym roku podatkowym, przedstawiając za-

${ }_{12}$ Por. art. 16 ustawy z dnia 28 listopada o świadczeniach rodzinnych, t.j. Dz. U. z 2006 r. $\mathrm{Nr}$ 139, poz. 992 ze zm.; ustawa z dnia 27 czerwca 2003 r. o rencie socjalnej, Dz. U. Nr 135, poz. 1268 ze zm.

${ }^{13}$ Ustawa z dnia 7 września 1991 r. o systemie oświaty, t.j. Dz. U. z 2004 r. Nr 256, poz. 2572 ze zm.

${ }^{14}$ Ustawa z dnia 27 lipca 2005 r. Prawo o szkolnictwie wyższym, t.j. Dz. U. z 2012 r., poz. 572. 
świadczenie wydane przez właściwy organ podatkowy innego niż Rzeczpospolita Polska państwa członkowskiego Unii Europejskiej lub innego państwa należącego do Europejskiego Obszaru Gospodarczego albo Konfederacji Szwajcarskiej, w którym osoby te mają miejsce zamieszkania, dla celów podatkowych lub inny dokument potwierdzający wysokość całkowitych przychodów osiągniętych w danym roku podatkowym.

W tym miejscu należy jednak odnieść się do pozostałych przesłanek, które warunkują stosowanie omawianej techniki opodatkowania. Analiza powołanego art. 6 ustawy pozwala przy tym na rozróżnienie katalogu przesłanek pozytywnych i negatywnych. Za pozytywne uznać należy te, które muszą zaistnieć, aby możliwe było zastosowanie algorytmu wyliczenia podatku właściwego dla opodatkowania osób samotnie wychowujących dzieci ${ }^{15}$. Warunki te muszą być spełnione łącznie - brak którejkolwiek z przesłanek wyklucza stosowanie wskazanej formy opodatkowania.

Pierwszą z nich jest „samotne wychowywanie dziecka w roku podatkowym”. Wykładnia językowa sformułowania „w roku podatkowym” pozwala na sformułowanie wniosku, że za wystarczające uznać należy istnienie przesłanek pozytywnych tylko przez część roku podatkowego ${ }^{16}$.

Najistotniejsze jednak wątpliwości związane są z rozumieniem terminu „wychowywanie". W tym zakresie należy odwołać się przede wszystkim do słownika języka polskiego, zgodnie z którym wychowywanie to zapewnienie bytu istocie niedorosłej i doprowadzenie do osiągnięcia przez nią pełnego rozwoju fizycznego i psychicznego ${ }^{17}$. W związku z tym „samotne wychowywanie" w rozumieniu ustawy o podatku dochodowym od osób fizycznych powinno być utożsamiane ze stałą troską o byt materialny i rozwój emocjonalny dziecka bez udziału innej osoby ${ }^{18}$.

Godny podkreślenia wydaje się fakt, że ustawodawca nawet w sposób pośredni nie posłużył się kryterium władzy rodzicielskiej jako rozstrzygającej o możliwości opodatkowania w omawiany sposób. Ta ostatnia jest definiowana przez doktrynę jako całokształt uprawnień i obowiązków rodziców względem małoletniego dziecka w celu zapewnienia pieczy nad jego osobą i majątkiem ${ }^{19}$. Zakres pojęcia „wychowywanie” nie pokrywa się zatem z zakresem sprawowania władzy rodzicielskiej ${ }^{20}$.

${ }_{15}$ Wyrok WSA z dnia 23 czerwca 2008 r., I SA/Kr 250/08, LEX nr 478625.

16 Por. A. Bartosiewicz, R. Kubacki, Ustawa o podatku dochodowym od osób fizycznych. Komentarz, Warszawa 2004, s. 82; R. Kubacki, Leksykon podatku dochodowego od osób fizycznych, Wrocław 2010, s. 131; odmiennie wyrok WSA z dnia 12 lutego 2008 r., I SA/Kr 1200/07, LEX nr 464235.

17 E. Sobol (red.), Mały stownik języka polskiego. Wydanie nowe, Warszawa 2000, s. 1157.

18 Wyrok NSA z dnia 5 października 2010 r., II FSK 890/09, LEX nr 668542.

19 T. Smyczyński, Prawo rodzinne i opiekuńcze, Warszawa 2009, s. 212.

${ }^{20}$ A. Nita, Glosa do wyroku NSA z dnia 7 marca 2001 r. (I SA/Gd 1799/98), POP 2003, nr 2, s. 180-181; odmiennie: wyrok NSA z dnia 7 marca 2001 r., I SA/ Gd 1799/98, ONSA 2002, z. 2, poz. 79; wyrok NSA z dnia 12 września 2008 r., II FSK 911/07, LEX nr 517953. 
W świetle postanowień ustawy o podatku dochodowym od osób fizycznych osobą samotnie wychowującą dzieci jest rodzic lub opiekun prawny, który jest panną, kawalerem, wdową, wdowcem, rozwódką, rozwodnikiem albo osobą, w stosunku do której orzeczono separację w rozumieniu odrębnych przepisów. Za osobę samotnie wychowującą dzieci uważa się również osobę pozostającą w związku małżeńskim, jeżeli jej małżonek został pozbawiony praw rodzicielskich lub odbywa karę pozbawienia wolności. Za wadliwe należy przy tym uznać niedookreślenie minimalnego okresu odbywania takiej kary w trakcie roku podatkowego. Może to prowadzić do zastosowania metody opodatkowania właściwej dla osób samotnie wychowujących dzieci w stosunku do podatnika, którego małżonek rozpoczął odbywanie kary w ostatnim dniu roku podatkowego. Niemożliwe jest natomiast uznanie za osobę samotnie wychowującą dziecko innej osoby fizycznej niż wymieniona w ustawie ${ }^{21}$.

Wskazane zasady ustawowe i jednoczesny brak jakichkolwiek dodatkowych kryteriów rozstrzygających, który z rozwiedzionych rodziców samotnie wychowuje dziecko, stanowią przyczynę istotnych wątpliwości interpretacyjnych. Przyjąć można, że o uprawnieniu tym powinien przesądzać tytuł prawny, jakim jest orzeczenie sądowe o sprawowaniu władzy rodzicielskiej ${ }^{22}$. Nie daje jednak podstaw do takiego rozstrzygnięcia wyrok, na podstawie którego pełnię praw rodzicielskich posiadają oboje rozwiedzieni rodzice. W orzecznictwie wskazano, że wyrok rozwodowy, w którym ustalono miejsce zamieszkania dziecka, przesądza o tym, który z rodziców jest osobą samotnie je wychowującą ${ }^{23}$. Postulować jednak należy o doprecyzowanie przepisu w tym zakresie. Zasadne wydaje się wprowadzenie pomocniczego, dodatkowego kryterium, którym mogłoby być zamieszkiwanie dziecka z rodzicem.

Kolejną pozytywną przesłankę warunkującą stosowanie preferencyjnej formy opodatkowania stanowi status wychowywanego dziecka. Z przepisu ustawy wynika, iż dokonano rozróżnienia na trzy grupy dzieci, których wychowywanie pozwala osobie samotnej na stosowanie specyficznej techniki opodatkowania. Są to przede wszystkim dzieci małoletnie. W tym przypadku należy jednak uwzględnić zasadę odnoszącą się do opodatkowania dochodów małoletnich dzieci własnych i przysposobionych, wyrażoną $\mathrm{w}$ art. 7 ustawy. Zgodnie z powołanym przepisem dochody małoletnich dzieci, z wyjątkiem dochodów z ich pracy ${ }^{24}$, stypendiów oraz dochodów z przedmiotów oddanych im do swobodnego użytku, podlegające

${ }^{21}$ Wyrok NSA z dnia 24 kwietnia 1998 r., III SA 1528/96, LEX nr 34700; wyrok NSA z dnia 7 stycznia 1998 r., I SA/Gd 716/96, LEX nr 35898.

22 Wyrok NSA z dnia 7 marca 2001 r., I SA/Gd 1799/98, ONSA 2002, nr 2, poz. 79.

23 Wyrok WSA z dnia 7 sierpnia 2009 r., I SA/Łd 467/09, LEX nr 552639.

${ }^{24}$ Zgodnie z interpretacją indywidualną Dyrektora Izby Skarbowej w Bydgoszczy z dnia 10 sierpnia 2010 r., ITPB2/415-480/10/MM, www.mf.gov.pl, opodatkowanie dochodu ze sprzedaży wizerunku małoletniej córki dla celów reklamy jest związane ze sprzedażą wizerunku, nie można zatem zakwalifikować uzyskanych przez nią przychodów do przychodów z pracy. 
opodatkowaniu na terytorium Rzeczypospolitej Polskiej, dolicza się do dochodów rodziców, chyba że rodzicom nie przysługuje prawo pobierania pożytków ze źródeł przychodów dzieci. Jeżeli małżonkowie podlegają odrębnemu opodatkowaniu, dochody małoletnich dzieci dolicza się po połowie do dochodu każdego z małżonków; zasady tej nie stosuje się do małżonków, w stosunku do których orzeczono separację w rozumieniu odrębnych przepisów. W tym przypadku sumowanie dochodów dziecka przybiera formę obowiązkowej kumulacji, która może prowadzić do podwyższenia wysokości podatku. Z drugiej jednak strony przyjęcie takiej formuły jest uzasadnione; powinno eliminować zjawisko sztucznego przesuwania składników majątku między członkami rodziny, którego celem byłoby obniżenie ciężaru podatkowego.

Z charakteryzowanej metody opodatkowania mogą korzystać również osoby samotnie wychowujące dzieci bez względu na wiek, które zgodnie z odrębnymi przepisami otrzymywały zasiłek pielęgnacyjny lub rentę socjalną. Odrębnymi przepisami są w tym przypadku przepisy ustaw: o świadczeniach rodzinnych ${ }^{25}$, o rencie socjalnej ${ }^{26}$.

Przyjęcie powyższego rozwiązania powinno być oceniane pozytywnie, realizuje ono bowiem przesłanki społeczne. Należy zauważyć, że opieka nad dzieckiem niepełnosprawnym w wielu przypadkach ogranicza, a nawet wyklucza możliwości zarobkowe osoby wychowującej dziecko ${ }^{27}$. Może być także związana z ponoszeniem zwiększonych wydatków na leczenie lub rehabilitację. W związku z tym każda forma wsparcia, rozumianego również jako redukcja obciążenia podatkowego, zasługuje na aprobatę.

Trzecią grupę dzieci, których wychowywanie uprawnia do stosowania omawianej metody opodatkowania stanowią, jak już zasygnalizowano, dzieci pełnoletnie, jednak do ukończenia 25. roku życia, uczące się w szkołach, o których mowa w przepisach o systemie oświaty, przepisach o szkolnictwie wyższym

${ }^{25}$ Ustawa z dnia 28 listopada 2003 r. o świadczeniach rodzinnych, t.j. Dz. U z 2006 r. Nr 139, poz. 992 ze zm. Zgodnie z art. 16 powołanej ustawy, zasiłek pielęgnacyjny przyznaje się w celu częściowego pokrycia wydatków wynikających z konieczności zapewnienia opieki i pomocy innej osoby w związku z niezdolnością do samodzielnej egzystencji. Zasiłek pielęgnacyjny przysługuje m.in.: 1) niepełnosprawnemu dziecku; 2) osobie niepełnosprawnej w wieku powyżej 16. roku życia, jeżeli legitymuje się orzeczeniem o znacznym stopniu niepełnosprawności. Zasiłek pielęgnacyjny przysługuje także osobie niepełnosprawnej w wieku powyżej 16. roku życia legitymującej się orzeczeniem o umiarkowanym stopniu niepełnosprawności, jeżeli niepełnosprawność powstała w wieku do ukończenia 21. roku życia.

${ }^{26}$ Ustawa z dnia 27 czerwca 2003 r. o rencie socjalnej, Dz. U. Nr 135, poz. 1268 ze zm. Na podstawie art. 4 ustawy, renta socjalna przysługuje osobie pełnoletniej całkowicie niezdolnej do pracy z powodu naruszenia sprawności organizmu, które powstało: 1) przed ukończeniem 18. roku życia; 2) w trakcie nauki w szkole lub w szkole wyższej - przed ukończeniem 25. roku życia; 3) w trakcie studiów doktoranckich lub aspirantury naukowej.

${ }^{27}$ W. Wójtowicz, Sytuacja prawnopodatkowa osoby samotnie wychowujacej dziecko niepetnosprawne, [w:] W. Miemiec (red.), Księga Jubileuszowa Profesora Ryszarda Mastalskiego. Stanowienie i stosowanie prawa podatkowego, Wrocław 2009, s. 466. 
lub w przepisach regulujących system oświaty lub szkolnictwo wyższe obowiązujących w innym niż Rzeczpospolita Polska państwie, jeżeli w roku podatkowym nie uzyskały dochodów podlegających opodatkowaniu według skali podatkowej lub dochodów z kapitałów pieniężnych w łącznej wysokości przekraczającej kwotę stanowiącą iloczyn kwoty zmniejszającej podatek oraz stawki podatku, określonych w pierwszym przedziale skali podatkowej, z wyjątkiem renty rodzinnej. Jak z tego wynika, uzyskanie pełnoletniości przez dziecko nie musi automatycznie wykluczać osoby samotnie wychowującej to dziecko z kręgu podatników rozliczających swój dochód w sposób preferencyjny. Istotne jest jednak, aby spełnione były w dalszym ciągu kumulatywnie dwie przesłanki, tzn. aby dziecko pobierało naukę i nie osiągało dochodów w sposób i w wysokości wskazanych w ustawie.

W kontekście powyższych ustaleń warto uzupełnić, że w przypadku podatnika wychowującego samotnie więcej niż jedno dziecko wystarczające jest, aby wskazane przesłanki odnoszące się do dzieci były spełnione przez jedno z nich.

Ostatnim z warunków, które muszą zostać spełnione, aby obliczenie podatku mogło być dokonane w charakteryzowany sposób, jest złożenie wniosku w tym przedmiocie, wyrażonego w zeznaniu podatkowym. W aktualnie obowiązującym stanie prawnym złożenie tego wniosku musi nastąpić w terminie właściwym dla złożenia zeznania podatkowego za rok podatkowy. Niedotrzymanie tego terminu skutkuje utratą prawa do stosowania specyficznej formy opodatkowania i może być zaliczone do grupy przesłanek negatywnych.

W tym miejscu należy wskazać na pozostałe przesłanki umownie zaliczone do tej grupy. Warto dodać, że nie mogą one istnieć zarówno po stronie podatnika, jak i dziecka przez niego wychowywanego. I tak, metoda opodatkowania właściwa dla osób samotnie wychowujących dzieci nie znajduje zastosowania w przypadku, gdy osoba samotnie wychowująca dzieci lub jej dziecko wybrali proporcjonalny sposób opodatkowania prowadzonej działalności gospodarczej lub opodatkowanie tej działalności na podstawie ustawy o zryczałtowanym podatku dochodowym ${ }^{28}$ lub ustawy z dnia 24 sierpnia 2006 r. o podatku tonażowym ${ }^{29}$.

Możliwość opodatkowania $\mathrm{w}$ omawiany sposób wiąże się bezpośrednio z zastosowaniem wspomnianego już algorytmu, w oparciu o który obliczana jest wysokość podatku. Określa się go w podwójnej wysokości podatku obliczonego od połowy dochodów osoby samotnie wychowującej dzieci, z uwzględnieniem kumulacji dochodów dzieci małoletnich, z tym że do sumy tych dochodów nie wlicza się dochodów (przychodów) opodatkowanych w sposób zryczałtowany na zasadach określonych w ustawie o podatku dochodowym od osób fizycznych. Warto zwrócić uwagę, że sposób wyliczenia podatku jest stały i nie zależy od liczby wychowywanych dzieci.

28 Ustawa z dnia 20 listopada 1998 r. o zryczałtowanym podatku dochodowym od niektórych przychodów osiąganych przez osoby fizyczne, Dz. U. Nr 144, poz. 930 ze zm.

29 Ustawa z dnia 24 sierpnia 2006 r. o podatku tonażowym, Dz. U. Nr 183, poz. 1353 ze zm. 
Reasumując, należy stwierdzić, że charakteryzowana instytucja, pomimo sygnalizowanych mankamentów, generalnie zasługuje na uznanie. Może być bowiem traktowana jako element podatkowej polityki prorodzinnej, tak istotnej zwłaszcza w społeczeństwach starzejących się. Równocześnie należy stwierdzić, że reguły opodatkowania osób samotnie wychowujących dzieci podlegają sukcesywnym zmianom, dla których charakterystyczne jest uszczegółowienie regulacji prawnych. Jest to podyktowane z jednej strony rozwojem stosunków społecznych oraz prawnych, z drugiej - koniecznością uszczelnienia systemu podatkowego. W pewnych obszarach zauważalna jest liberalizacja stanowiska ustawodawcy. Niezależnie od tego należy uznać, że instytucja opodatkowania osób samotnie wychowujących dzieci na trwałe wpisała się w konstrukcję podatku dochodowego od osób fizycznych. 